\title{
Open Fractures - Time from Trauma to Efficient Surgical Debridement Is the Key Factor for Post-Traumatic Infection
}

Olivera Lupescu', Mihail Nagea², Alexandru Lisias Dimitriu', Nicolae Marian Ciurea², Alina Grosu², Gheorghe Ion Popescu'

\begin{abstract}
Open fractures represent a challenging aspect of modern traumatology with high individual and social impact especially due to septic complications which require prolonged hospitalization, repeated surgery and considerable costs. That is why medical research is directed to establishing the most efficient diagnostic and therapeutic algorithms able to decrease the incidence of septic complications and promote optimal fracture healing. The purpose of this paper is to underline the importance of early proper surgical debridement for the outcome of these fractures as reflected by the experience of a Level 1 Trauma Centre in order to include this aspect into future therapeutical guidelines.
\end{abstract}

Keywords: open fractures, surgical debridement, external fixation

\section{Rezumat}

Fracturile deschise reprezintă un aspect dificil al traumatologiei moderne, cu impact atât individual, cât și social, datorită în primul rând complicațiilor septice, ce necesită spitalizări prelungite, multiple intervenții chirurgicale și generează costuri considerabile. Din aceste considerente cercetarea medicală este îndreptată spre stabilirea celor mai eficiente protocoale diagnostice și terapeutice care să asigure vindecarea optimă și diminuarea incidenței complicațiilor septice. Obiectivul acestei lucrări este de a sublinia importanța debridării chirurgicale precoce în tratamentul acestor fracturi, ilustrată de experiența unui Centru de Traumă de nivel 1, ca premisă a includerii acestui aspect în ghidurile și protocoalele terapeutice.

Cuvinte cheie: fracturi deschise, debridare chirurgicală, fixare externă

\section{INTRODUCTION}

Open fractures are characterized by the direct communication between the fracture site and the exterior, due to a injury of the skin and surrounding soft tissues. Several classifications of these fractures have been used, none of them describing all the complex features of these injuries. The most widely used nowadays is the one introduced by Gustillo and Anderson ${ }^{1}$, which describes 3 type of open fractures,

- Type I- clean wound less than $1 \mathrm{~cm}$ in size.

- Type II- wound over $1 \mathrm{~cm}$ length, no extensive soft tissue damage, no flaps, nor avulsions.

- Type III- extensive soft-tissue damage; regardless the aspect of the wound, gunshot and farm injuries, and fractures open for more than $8 \mathrm{hrs}$
1 Clinic of Orthopaedics and Trauma, Clinical Emergency Hospital, „Carol Davila" University of Medicine and Pharmacy, Bucharest, Romania

${ }^{2}$ Clinic of Orthopaedics and Trauma, Clinical Emergency Hospital, Bucharest, Romania
Corresponding author.

Olivera Lupescu, Clinic of Orthopaedics and Trauma, Clinical Emergency Hospital, $8^{\text {th }}$ Calea Floreasca, 014461, Bucharest, Romania.

E-mail: olivera_lupescu@yahoo.com 
prior to treatment must be included in type III; 3 sub-types have been identified:

- Type III A- despite extensive soft tissue damage, adequate periosteal coverage of the fracture site still exists.

- Type III B- extensive soft tissue damage, periosteal stripping, massive contamination, primary coverage of the fracture site is not possible, requiring secondary coverage procedure.

- Type III C - injury of one major artery, clinical signs of acute peripheral ischaemia, surgical restoration of the arterial axis is absolutely necessary for the vitality of the limb, irrespective of the associated soft tissue damage.

The finality of this classification refers primarily to the prognosis of the patient: the traumatic energy increases from type I to type III, so do the soft tissue damage and the contamination, thus worsening the local prognosis; according to the data published by Gustillo $^{2}$, Zalavras ${ }^{3}$ and $\mathrm{Cross}^{4}$, the infection risk has been evaluated to be from 0 to $2 \%$ for Type I fractures, 2 to $10 \%$ for Type II fractures, and 10 to $50 \%$ for Type III fractures.

The patophysiology of open fractures is related to the exposure syndrome, consisting of all the phenomena induced by the changes in $\mathrm{pH}$, temperature, humidity, chemical composition produced when the tissues are exposed to the external conditions, totally different from those of the internal environment. This syndrome affects the metabolism of the tissues, but mainly the microcirculation which suffers multiple disturbances:

- increased capillary permeability, with leakage and subsequent increased blood viscosity;

- stasis in the capillaries and the phenomenon described as ,sludge", consisting in increased adherence of the blood cells, which aggregate themselves;

Together with increased amount of tissular thromboplastine, a strong pro-thrombotic element, these generate the conditions described as the "Virchow Triade", leading to thrombosis within the capillaries, and generating secondary tissular necrosis, which enhance the initial post-traumatic injuries. It has been demonstrated that the only element which can protect the already injured tissue from further damage due to microcirculation disturbances is oxygen, therefore it is mandatory for the injury site to have only vital tissues ${ }^{5}$.

The treatment of open fractures includes both general and local elements; the purpose of this paper is to focus on surgical treatment, therefore the general treat- ment will not be approached in detail.

The local treatment must address to all the injuries and to clean the fracture site until it contains only vital tissue, able to promote healing, no matter if we speak about the muscle or about the bone.

The purpose of this paper is to evaluate the efficacy of the protocol for treating open fractures in a Level 1 Trauma Centre, Clinical Emergency Hospital, in order to underline the main therapeutic aspects able to decrease the risk of infection.

\section{MATERIAL AND METHOD}

A retrospective study was performed in the Clinical Emergency Hospital Bucharest, a Level 1 Trauma Centre, regarding open fractures operated between 01.06.2010-01.06.2015, with a minimum of 24 months follow-up after trauma. From 542 patients with open injuries, only 343 completed the follow-up, thus being included in this study. The criteria used for this analysis were: demographic (age and gender) as well as pathogenic criteria (the type according to Gustillo classification), as well as those related to treatment assesment, with three components: type of bone stabilisation, time from trauma to the first antibiotic dose, time from trauma to surgical complete debridement. The outcome was described by the incidence of infections within the first 24 months after trauma.

\section{RESULTS}

Regarding the demographic analysis, 67\% (230) of the patients were males, who seem to be more frequent involved in high energy trauma, and most of them were active people, 117 patients (34\%) being under $30 \mathrm{yrs}$ old, 82 patients between $31-45$ yrs (28\%), 89 patients (26\%) between 45-60 yrs and the rest of them over 60 yrs old. These results confirms the socila importance of an optimal treatment of open fractures, as early social and professional reinsertion of these patients must be final goal of the treatment.

An aspect which must be discussed is the time between trauma to complete specialised treatment; although open fractures represent an emergency, and debridement is recommended to be performed within $6 \mathrm{hrs}$ after trauma, still, in the study group, the time between trauma to debridement (Figure 1a) was more than 6 hrs in most of the patients, even more than $24 \mathrm{hrs}$, which considerably increases the risk of infection. It must be underlined that, once arrived at the Emergency Hospital, the patients were immediately operated, so this 


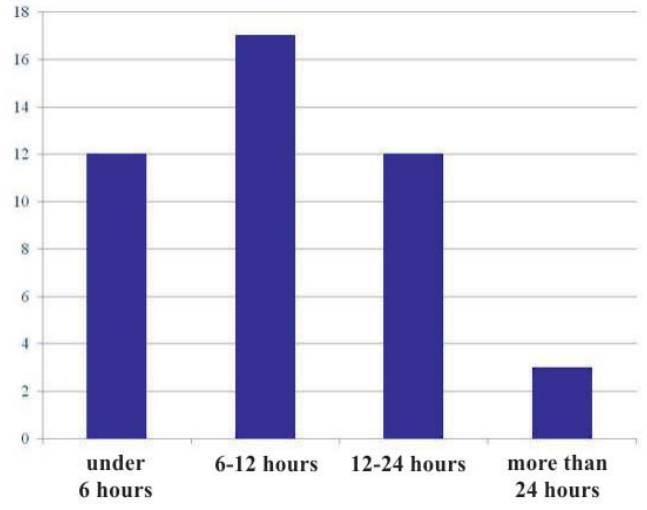

A

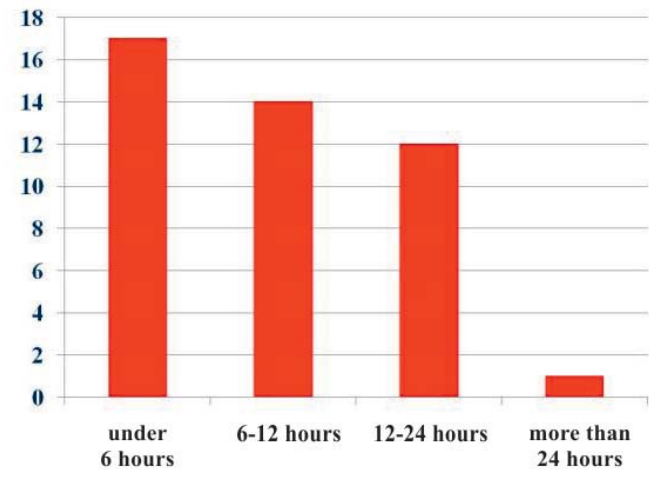

B

Figure 1. Time from trauma to debridement (A) depends on the moment of admission (A) at the Trauma Centre.

delay was determined by the interval between trauma and the admission (Figure 1b). The fact that there were still patients who were sent late to a Trauma Centre without proper debridement must be discussed with all the factors involved and must be amended, given the crucial importance of time under these circumstances

The protocol for these patients consisted in:

- initial multidisciplinary evaluation in the Emergency Room (ER), in order to establish the priority of different injuries especially in polytrauma; this aspect was tackled according to the ATLS rules, and it will not be detailed in this paper; standard tests (lab tests, ECG, pulmonary Xrays) were urgently performed in all the patients.

- administration of anti-tetanic vaccine.

- lavage with sterile solutions after preliminary skin preparation.

- sterile dressing and temporary cast, as pre-operative measures.

According to the protocol of the Orthopaedics and Trauma Clinic, the following where applied to the study group and must be underlined:

- Figure 1. Time from trauma to debridement (a) depends on the moment of admission (a) at the Trauma Centre it is forbidden to explore the wound in the ER, due to risk of bleeding and supplementary contamination; this must be performed in the Operation Room (OR).

- Figure 1. Time from trauma to debridement (a) depends on the moment of admission (a) at the Trauma Centre it is forbidden to suture an open fracture in the ER; the opportunity of suturing an open fracture will be decided only after debridement.
- Figure 1. Time from trauma to debridement (a) depends on the moment of admission (a) at the Trauma Centre the indication for placing a tourniquet will be only for severe, uncontrollable bleedings; compressive bandage should be used a first choice.

Therefore, all the manoeuvres upon the open fractures in the study group were performed in the OR, were general treatment must be continued and specialised local treatment must be started as soon as possible. Regarding the general treatment, in the study group, antibiotic treatment was administered at the induction of anaesthesia, but for some of the patients, previous antibiotic treatment was administered in the hospital where the patients had been treated before coming to our Hospital (Figure 2). It is not the purpose of this study to evaluate the efficacy of the type of different antibiotic schemes, but prospective randomised studies

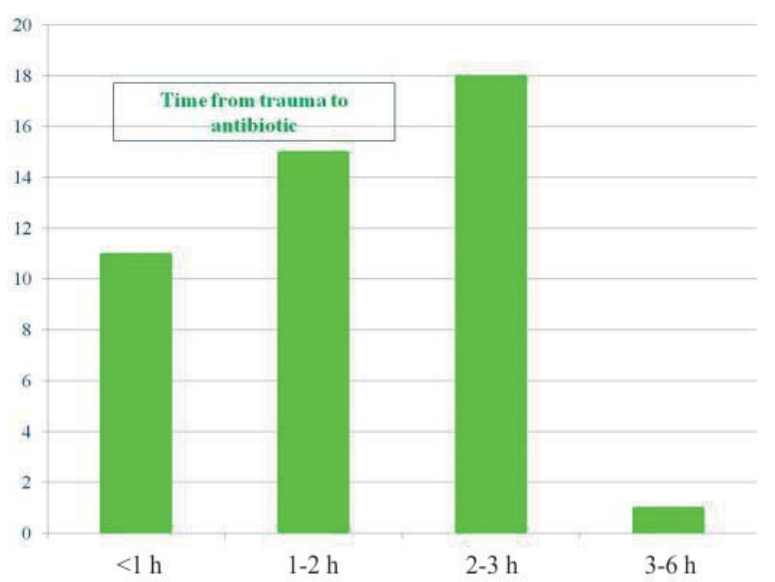

Figure 2. Time from trauma to first antibiotic administration. 
focused on this idea would be of great benefit for improving the outcome of these patients.

Local treatment in the OR: after removal of the initial bandage and cast, the skin was prepared - the hair was removed on a larger area, covering the estimated size of the final incision. The most important steps identified in the treatment of the patients in the Study Group were:

a) Assessment; the wound must be explored and the surgeon must decide whether it is necessary to prolong it proximally or distally, so as to have full access to all the injured spaces and structures; the following elements must be assessed:

- vascular and nervous damage; it must be decided if intra-operative evaluation must be completed by the plastic or vascular surgeons.

- soft-tissue damage- muscular, facial, and periosteal.

- bone injuries: isolated bone fragments must be considered potential sequesters, and periosteal stripping is a sign of future bone avascularity. Only after these are evaluated, the fracture can be properly classified according to Gustillo; in the study group (Figure 3a), most of the fractures where Type I, but, as can be seen, $25 \%$ of the fractures were severe injuries, type III. As it will be detailed later, this is directly correlated with the type of fixation; in the study group (Figure $3 b)$, internal fixation was mainly used for type I and II of open fractures, while for type III, external fixation (ExFix) was the method of choice.

- degree of contamination- although it can be correlated with the severity of soft -tissue in- juries, the bacterial loading can be directly assessed and can provide interesting data. From the study group, in 76 patients, initial swabs and tissue samples were used for microbiological evaluation; in 60 cases, as shown in Figure $4 \mathrm{a}$, bacterial growth was proven; an interesting aspect is described in Figure 4b, which shows not only that, up to a certain extent, initial contamination was followed by infections with the same types of bacteria; as not all the study group had this aspect studied, we cannot draw a general conclusion, but the identical types of bacteria suggest a strong connection between initial contamination and late infection; in the same time, the reduced rate of infection compared to that of the initial contamination in this subgroup demonstrates the efficacy of treatment.

b) Lavage with sterile solutions; the following can be used: ionic organic detergents, hydroxyl-peroxide, then saline/Ringer solution, avoiding glucose solution, so as not to create a favourable environment for the bacteria); large quantities of solutions were used for repeated lavage series, in order to clean the fracture site.

c) Debridement was performed for all the involved structures, until the fracture site contained only vital tissues; according to the medical data of the patients, vitality was assessed according to the following aspects.

- the muscles - must be read, bleeding when excised and contractile when electrically or mechanically stimulated.

- the fascia must be adherent to the subjacent muscle.

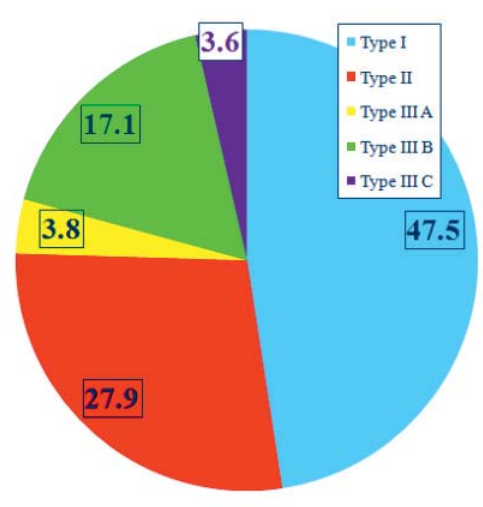

A

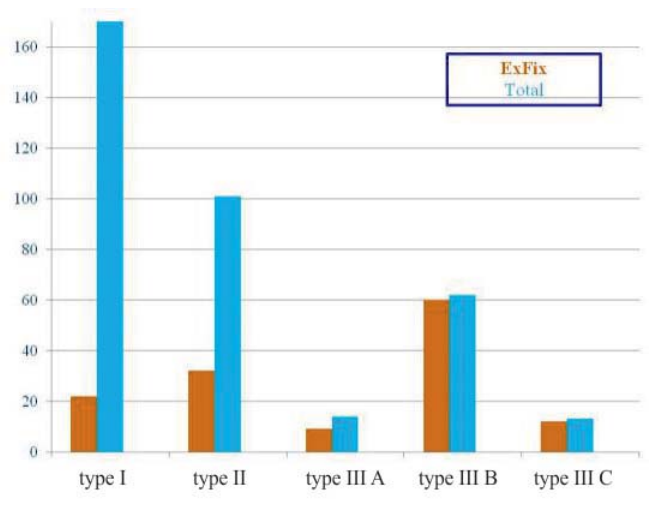

B

Figure 3. Type of the fracture (Gustillo) established after intra-operative evaluation (A), determining the type of fixation (B). 


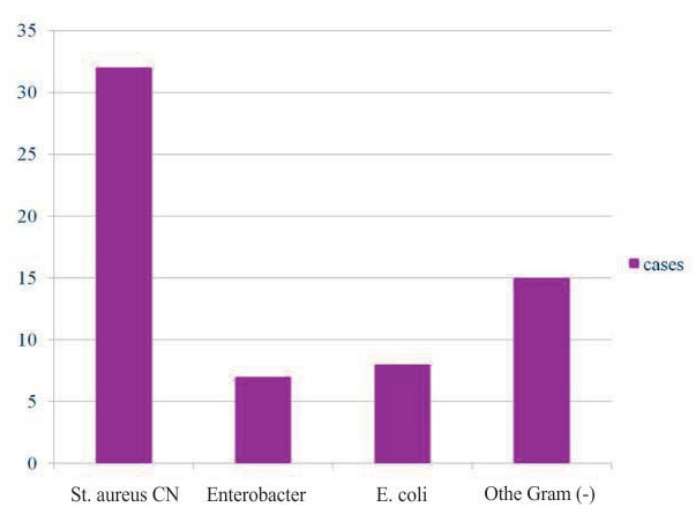

A

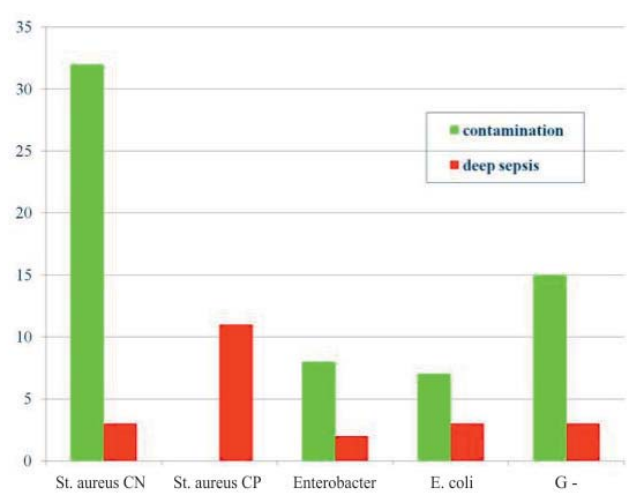

B

Figure 4. Initial contamination (A) correlated with deep sepsis (B).

- the periosteum must be adherent to the subjacent bone.

- the bone must be covered by adherent periosteum and bleeding when scratched or cut.

- the vitality of the skin is debatable if it has areas of direct contusion, degloving, subcutaneous thrombosis; these can be kept in place, if they are not definitely necrotic, but only under careful monitoring, so as to make the proper decision in due time.

In the study group, repeated debridements were performed, with intercalated lavages, followed by a final evaluation of the fracture site; based on this, the next step of the treatment was approached.

d) Specific treatment of bone and soft tissue injuries;

- bone stabilisation was performed, as previously presented, based on the intra-operative postdebridement assessment; although it refers to the bone and it must be adapted to the fracture pattern, the type of osteosynthesis (internal vs external) mainly depends on 2 other factors: the degree of contamination and the status of the soft tissue; therefore, in severe open fractures (type III, especially B), with high degree of bacterial load, muscular injuries and periosteal stripping, external fixation is considered to reduce the septic risk. In these cases, the so-called sequential method was used: primarily external fixation, followed by internal stabilisation after the soft tissues have healed.

- In IIIC open fractures, a specific protocol was applied: rapid bone stabilisation by ExFix, arte- rial restoration, then fasciotomy for preventing the reperfusion syndrome

- treatment of associated soft tissue injuries was performed by reconstructive methods or by temporary means until definitive restoration was possible.

e) Treatment after primary debridement consisted in repeated debridements and lavages in the OR, until the soft tissue healed. In 53 cases, negative pressure therapy was used, with good results.

The incidence of infection was $7.2 \%$, significantly higher for type III $(p<0.05)$ (Figure 5), but with no correlation between the incidence of infection and the type of stabilisation. The incidence of infection was significantly correlated with the time between trauma and first debridement; as shown in Figure 6a. More than that, as shown in Figure 6b, time between trauma and

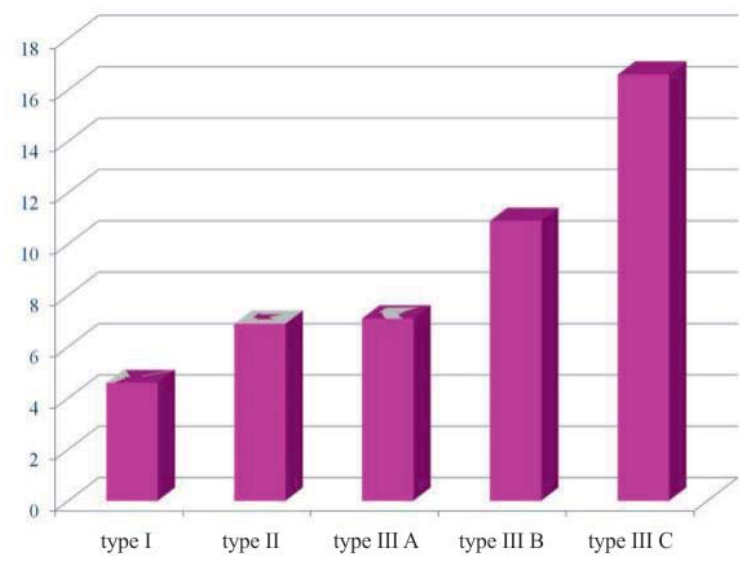

Figure 5. Incidence of infection in different types of open fracture in the study group. 


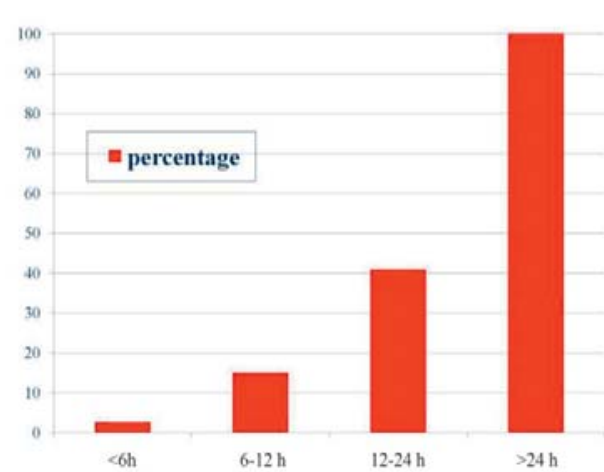

A

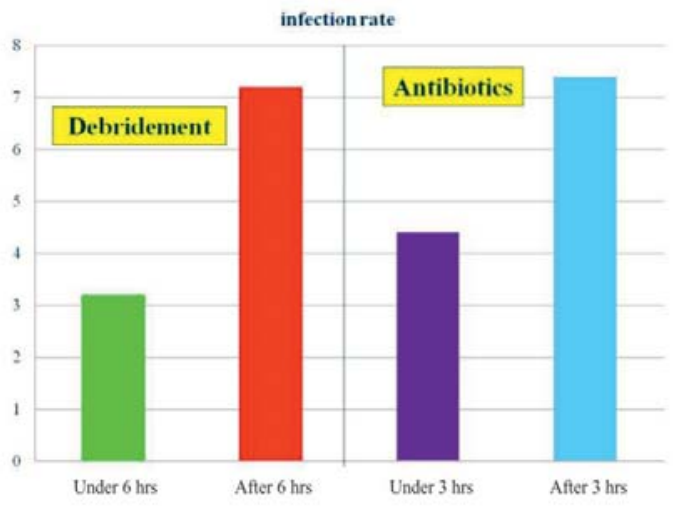

B

Figure 6. Correlation between infection and time until first debridement $(A)$ and the comparative influence of time to debridement vs time to antibiotic (B).

antibiotic treatment significantly increased the incidence of sepsis from $4.4 \%$ (antibiotics before $3 \mathrm{hrs}$ ) to $7.4 \%$ (antibiotics after $3 \mathrm{hrs}$ ), while time from trauma to debridement increased the risk from $3.2 \%$ (debridement before $6 \mathrm{hrs}$ ) to $7.2 \%$ for debridement after $6 \mathrm{hrs}$.

In order to illustrate the protocol of treating open fractures in the study group, we present a case of a 27 yrs old male who sustained a train accident, with severe crushing injury of the shank, with an open injury (Figure 7a). The Xray showed the comminuted character of the fracture (Figure $7 \mathrm{~b}, \mathrm{c}$ ), suggesting a high energy trauma.

Considering the aspect of the wound, there is some muscular damage, with no other obvious element if we

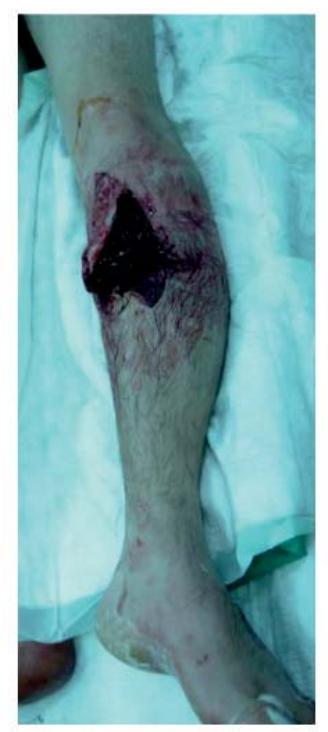

Figure 7. Train accident; open injury (A) with comminute fracture $(B, C)$. stick just to inspection; in the ER, a sterile bandage and a temporary cast were used, then the patient was immediately prepared for surgery.

Intra-operative assessment showed periosteal stripping, with multiple isolated bone fragments (Figure 8 $\mathrm{a}, \mathrm{b})$ in the post-traumatic wound, situated on the internal aspect of the shank. Because clinical evaluation revealed that the muscles on the external aspect of the shank seemed discontinuous, suggesting muscular ruptures, therefore an exploratory incision was performed adjacent to these areas (Figure 8c).

Although the skin was intact on this side, after incision, muscular pieces from the anterior and external groups herniated; the colour is suggestive (Figure 8c,

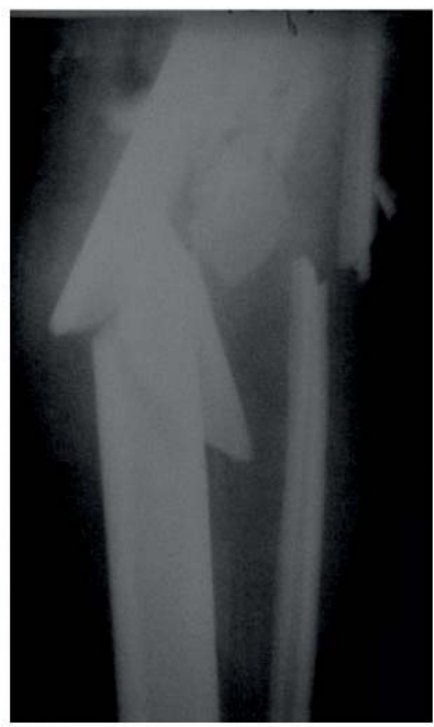

B

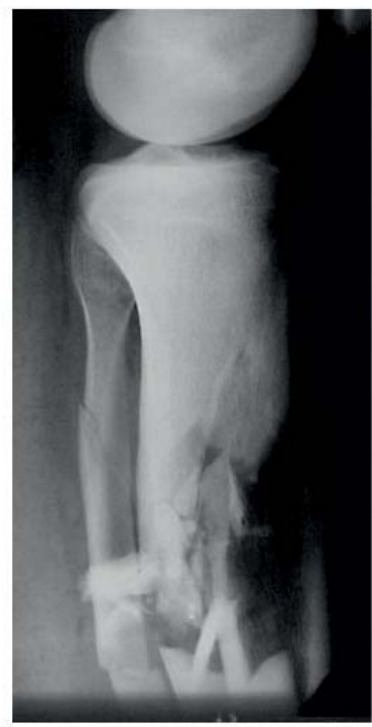

C 


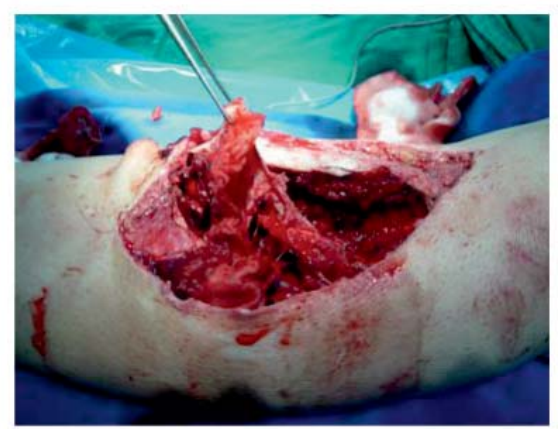

A

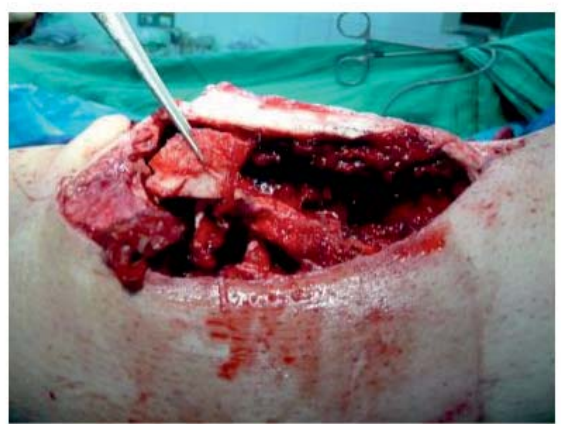

B

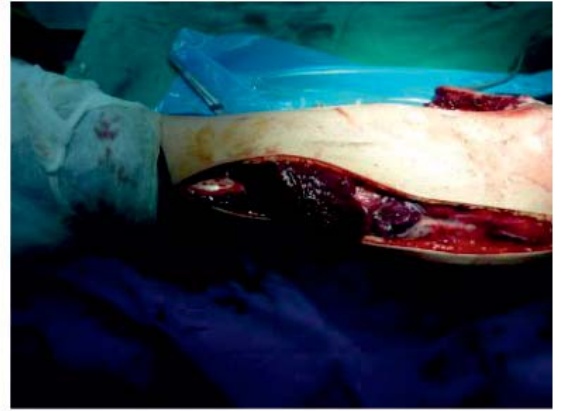

$\mathrm{C}$

Figure 8. Intra-operative assessment, with periosteal stripping (A, B) and muscular damage (C).

9a) for muscular necrosis, and lack of bleeding and contractility required thorough excision up to health tissue. The amount of destruction was considerably higher (Figure 9b) than suggested by the initial pre-operative aspect, thus classifying the fracture into type III B. The difference between the initial wound and the complex defect generated by the excision of all devitalised tissues (Figure $9 \mathrm{~b}$ ) is outstanding and it raises the question of the outcome of the patient had this excision not been performed; considering the amount of necrotic tissue that was removed from the fracture site, it is obvious that the risk of infection would have been considerable if proper debridement had not been performed. Serial lavages and debridements were performed until only vital tissue remained at the fracture site.

Due to the extensive muscular and periosteal damage, external fixation (Figure 9c) was the method of choice for immediate fixation of the fracture; after the soft tissue healed, the ExFix was removed and definitive intramedullary fixation was performed. The outcome was favourable, with proper healing and no signs of infection. The conclusion of this case is that treatment must be based on proper intra-operative evaluation of the injuries and must be represented by thorough debridement and lavage followed by adequate bone fixation.

\section{DISCUSSIONS}

Due to the complexity of open fractures, treatment is challenging and the outcome of the patient can be influenced by many factors. Still, certain aspects are unanimously recognized and are underlined by the present research: the outcome of open fractures depends mainly on the vitality of the structures, both post-traumatic, (influences by the traumatic energy), and after the first debridement.

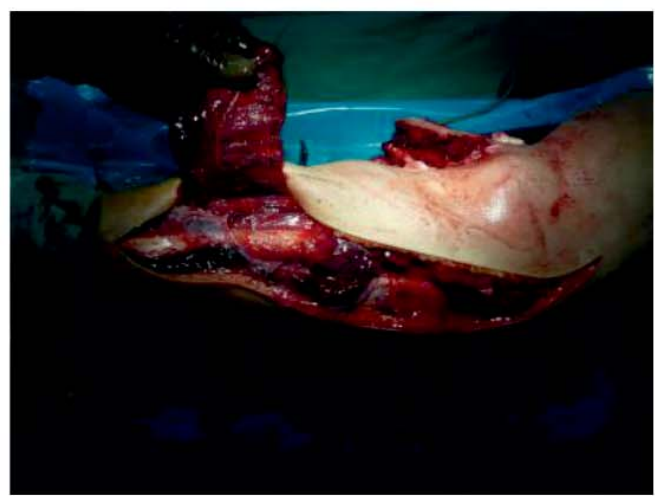

A

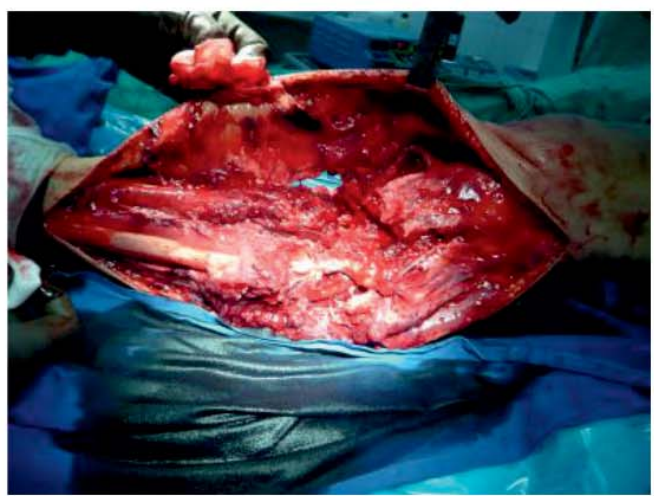

$\mathrm{B}$

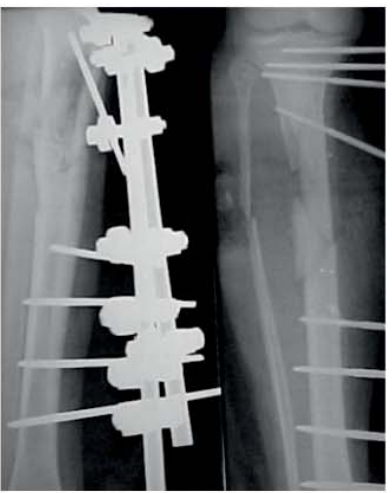

C

Figure 9. Extensive muscular damage in an apparently uninjured area (A) and complete aspect of the damages (B) requiring external fixation (C) as stabilisation method for the fracture. 
The wound must not be explored in the E.R., and, since the open fractures are always contaminated, no exteriorized bony fragment should be introduced under the skin, in its' original place, unless after lavage and surgical debridement ${ }^{6}$.

The proper description of the injuries must be performed within surgery, not at the Emergency Room; certain aspects with practical significance must be underlined regarding the Gustillo-Andersen classification: the size of the wound is not directly correlated with the severity of the subjacent injuries; it is not used as a parameter for type III open fractures, the most severe, because the most important element for the outcome of the patient is the status of the soft and bony tissue, and not the skin injuries ${ }^{7}$.

Once the injuries evaluated, the most important element is surgical debridement, performed according to the criteria for each tissue; it is recommended that following debridement, lavage should be repeated, than again debride, followed by lavage, so as at the end of this sequential lavage-debridements "chain”, the fracture site should contain only vital clean tissue. Although it can be said that it is difficult to assess the limits of the healthy tissue, only by clinical evaluation, still it must be underlined that performing a thorough excision following the above mentioned criteria considerably increases the chances to fulfil the goal of vitality, while leaving necrotic tissues on site under the pretext of not wanting to create a coverage defect will definitely expose the patient to septic complications; interdisciplinary cooperation with plastic surgery specialists can solve the problem of the defects, so thorough, complete excision must be performed in all circumstances; in the unusual situations when the vitality of some tissues is debatable, or, inside the same muscle, there is a very close vicinity between vital and uncertain areas, the alters can be left in place ONLY under careful local and general monitoring of the patient, with no more than $24 \mathrm{hrs}$ after the next surgical evaluation ${ }^{8-11}$.

Post-operative care is very important, as previously described. Besides the general monitoring of the patient, which must be performed in a multidisciplinary team, including the orthopaedic surgeon, the anaes- thetist, and, if necessary, other specialists, local care is crucial for the outcome of the patient; as secondary injuries may appear, determined by the disturbances in the microcirculation, thus resulting in the potentially progressive character of the injuries, repeated surgical evaluations must be performed after the first operation (usually called "second look”); it is mandatory for these to be performed in the OR, as for any surgical procedure, under strict sterile conditions, and they should include complete assessments of all the structures, and, if necessary, supplementary excisions, corrections of fixation, or other surgical methods with the same goal as the primary surgery ${ }^{12}$.

\section{CONCLUSIONS}

Open fractures are severe injuries, with high potential for local severe complications- chronic infections or even amputations. The injuries depend on the traumatic energy and affect all the structures of the injured segment. Treatment of open fractures represent a surgical emergency, the first 6 hours being considered crucial for the prognosis. The classification of the fracture must be based on complete intra-operative evaluation of the injuries must be performed in the OR. Thorough debridement is crucial for the outcome of the open fractures and must be completed by lavage and proper bone stabilization depending on the status of the soft tissues. The prognosis of open fractures is influenced both by the traumatic energy and by the vitality of the tissues in the fracture site, after debridement. Proper local and general monitoring, with repeated debridements and a flexible surgical attitude, adapted to the outcome of the patient can decrease the rate of complications and improve the quality of the life for these patients.

Compliance with ethics requirements: The authors declare no conflict of interest regarding this article. The authors declare that all the procedures and experiments of this study respect the ethical standards in the Helsinki Declaration of 1975, as revised in 2008(5), as well as the national law. Informed consent was obtained from all the patients included in the study. 


\section{References}

1. Gustily RB, Anderson JT. Prevention of infection in the treatment of one thousand and twenty-five open fractures of long bones: Retrospective and prospective analyses. J Bone Joint Surg Am. 1976;58:453-8.

2. Gustilo RB, Gruninger RP, Davis T. Classification of type III (severe) open fractures relative to treatment and results. Orthopedics. 1987;10:1781-8

3. Zalavras CG, Marcus RE, Levin LS, Patzakis MJ. Management of open fractures and subsequent complications. J Bone Joint Surg Am. 2007;89:884-95

4. Cross WW, Swiontkowski MF. Treatment principles in the management of open fractures. Indian J Orthop. 2008;42(4):377-86.

5. Mosheiff R. Open fractures. Buckley RE, Moran CG, Apivatthakakul T, eds. AO Principles of Fracture Management. 3rd ed. New York: Thieme; 2017.

6. Griffin M, Malahias M, Khan W, Hindocha S. Update on the management of open lower limb fractures. Open Orthop J 2012; $6: 571-7$

7. Kim PH, Leopold SS. In brief: Gustilo-Anderson classification. [corrected]. Clin Orthop Relat Res. 2012;470(11):3270-4.

8. Crowley DJ, Kanakaris NK, Giannoudis PV. Irrigation of the wounds in open fractures. J Bone Joint Surg [Br] 2007:89:5805.

9. Bhandari M, Jeray KJ, et al.; FLOW Investigators. A trial of wound irrigation in the initial management of open fracture wounds.N Engl J Med 2015;373:2629-41

10. Lachica RD. Evidence-based medicine: management of acute lower extremity trauma. Plast Reconstr Surg 2017;139:287e$301 e$.

11. Melvin JS, Dombroski DG, Torbert JT, et al. Open tibial shaft fractures: II. Definitive management and limb salvage. J Am Acad Orthop Surg 2010;18:108-17

12. Elniel, Abdel Rahim and Peter $\vee$ Giannoudis. "Open fractures of the lower extremity: Current management and clinical outcomes" EFORT open reviewsvol. 3,5 316-325. 21 May. 2018, doi:10.1302/2058-5241.3.170072. 
